\title{
Source Identification and Apportionment of Trace Elements in Soils in the Yangtze River Delta, China
}

\author{
Shuai Shao ${ }^{1}$, Bifeng Hu ${ }^{2,3,4}$, Zhiyi Fu ${ }^{1}$, Jiayu Wang ${ }^{1}$, Ge Lou ${ }^{1}$, Yue Zhou ${ }^{1}$, Bin Jin ${ }^{5}$, Yan Li ${ }^{6, *}$ \\ and Zhou Shi ${ }^{1}$ \\ 1 Institute of Applied Remote Sensing and Information Technology, Zhejiang University, Hangzhou 310058, \\ China; sshuai@zju.edu.cn (S.S.); fzy513432821@gmail.com (Z.F.); wangjiayu_zju@163.com (J.W.); \\ lllouxbai@outlook.com (G.L.); yuezhou@zju.edu.cn (Y.Z.); shizhou@zju.edu.cn (Z.S.) \\ 2 Science du Sol, INRA, 45075 Orléans, France; bifeng.hu@inra.fr \\ 3 Unité InfoSol, INRA, US 1106, 45075 Orléans, France \\ 4 Sciences de la Terre et de lthe'Univers, Orléans University, 45067 Orleans, France \\ 5 Ningbo Agricultural Food Safety Management Station, Ningbo 315000, China; dd923068626@163.com \\ 6 Institute of Land Science and Property, School of Public Affairs, Zhejiang University, \\ Hangzhou 310058, China \\ * Correspondence: liyan522@zju.edu.cn
}

Received: 20 May 2018; Accepted: 9 June 2018; Published: 12 June 2018

\begin{abstract}
Trace elements pollution has attracted a lot of attention worldwide. However, it is difficult to identify and apportion the sources of multiple element pollutants over large areas because of the considerable spatial complexity and variability in the distribution of trace elements in soil. In this study, we collected total of 2051 topsoil $(0-20 \mathrm{~cm})$ samples, and analyzed the general pollution status of soils from the Yangtze River Delta, Southeast China. We applied principal component analysis (PCA), a finite mixture distribution model (FMDM), and geostatistical tools to identify and quantitatively apportion the sources of seven kinds of trace elements (chromium $(\mathrm{Cr})$, cadmium $(\mathrm{Cd})$, mercury $(\mathrm{Hg})$, copper $(\mathrm{Cu})$, zinc $(\mathrm{Zn})$, nickel $(\mathrm{Ni})$, and arsenic $(\mathrm{As}))$ in soil. The PCA results indicated that the trace elements in soil in the study area were mainly from natural, multi-pollutant and industrial sources. The FMDM also fitted three sub log-normal distributions. The results from the two models were quite similar: $\mathrm{Cr}$, As, and $\mathrm{Ni}$ were mainly from natural sources caused by parent material weathering; $\mathrm{Cd}, \mathrm{Cu}$, and $\mathrm{Zu}$ were mainly from mixed sources, with a considerable portion from anthropogenic activities such as traffic pollutants, domestic garbage, and agricultural inputs, and $\mathrm{Hg}$ was mainly from industrial wastes and pollutants.
\end{abstract}

Keywords: trace elements; source identification and apportionment; principal component analysis (PCA); finite mixture distribution model (FMDM); Yangtze River Delta

\section{Introduction}

Trace elements pollution has attracted a lot of attention around the world [1-5]. There is much concern about trace elements-contaminated soils because of their high toxicity and resistance to degradation [6]. Trace elements pose high risks to health and ecosystem function when introduced to the human body and ecosystems via food chains, respectively [7-9]. The sources of soil trace elements are generally natural or anthropogenic [10,11]. Formerly, trace elements were mainly introduced to soils through weathering of parent materials but with rapid increases in urban, industrial, and agricultural activities, such as electronic plating, fossil fuel combustion, and agricultural chemical fertilizer abuse, in recent years, the high trace element concentrations in soil now mainly reflect human activities $[3,12]$. The geographical distribution of trace elements in soil is complex [7]. In order to repair polluted 
soils and prevent further soil pollution, we need to qualitatively and quantitatively identify and apportion the sources of trace elements. This information can help decision-makers understand how trace elements vary spatially and why their concentrations fluctuate erratically which is a necessary prerequisite to mitigating and preventing soil pollution [13].

Identifying and apportioning the sources of soil trace elements dates back to the 1970s [14]. Various methods, including chemical mass balance (CMB) [15], molecular markers (MM) [16], isotope tracing (IT) [17], UNMIX models [18], factor analysis (FA) [19], positive definite matrix factor analysis (PMF) [20], and multiple linear regression (APCS-MLR) [21], are currently used to identify the sources of trace elements in soil. Applications of such models are generally limited by their rigorous demands for preliminary information and numerous datasets comprising high resolution data, for example, about the number of pollution sources, properties of soils from the source areas, and the comparative stability of source transport processes [22,23].

Principle component analysis (PCA) is a widely-used multi-statistical analysis method whose purpose is to switch multidimensional data into a couple of relevant variables that simultaneously maintain the information involved in the original variables and diminish the dimensions of the data [24-26]. While finite mixture distribution model (FMDM) is a mathematical approach for statistical modeling of massive random data sets [27]. It can be applied to identify whether the trace elements from soil samples originate from a natural background or anthropogenic background, without knowing the general contaminated condition of the full areal extent of the study area [28,29]. But, to date, few studies have used and compared different models to identify the sources of trace elements. To fill this gap, in our study, we compared the abilities of PCA and FMDM to identify and apportion the sources of trace elements in soils in the Yangtze River Delta. The main objectives of this study were to (1) describe and estimate the concentrations and distribution of trace elements in soil and assess the pollution status of the Yangtze River Delta; (2) apply PCA and FMDM to determine the sources of seven trace elements over a large area; and (3) to confirm and apportion the main sources of trace elements in soil.

\section{Materials and Methods}

\subsection{Study Area and Sampling}

The study area is a crucial port in the Yangtze River Delta, China (Figure 1). The area is dominated by plains and low hills. It has an average elevation of about $4.2 \mathrm{~m}$ and the elevation generally decreases from the southwest to the northeast. A total of 2051 topsoil $(0-20 \mathrm{~cm})$ samples were collected from the study area, which was first divided into strata according to land use type, and systematic grid sampling was applied. At some of the grid nodes, grid sampling was augmented by sampling nearby areas (Figure 1). We collected a soil sample at an intersection point and combined it with five subsamples collected from five locations within $5 \mathrm{~m}$. The coordinates of the sampling locations were recorded with a differential global positioning system.

We air-dried the soil samples in the lab in ambient air for several days, then passed them through a 2-mm nylon sieve and save for further analysis of soil properties [30]. Soil $\mathrm{pH}$ was measured by the Glass Electrode method with a soil/solution of 1:2.5 ( $\mathrm{m} / \mathrm{v})$; The total concentration of $\mathrm{Cr}$, As, Cu, $\mathrm{Cu}, \mathrm{Zn}$, and $\mathrm{Ni}$ of soil samples were all digested with the acid $\mathrm{HCl}-\mathrm{HNO}_{3}-\mathrm{HClO}_{4}$ and total $\mathrm{Cd}$ was acid-digested with $\mathrm{HF}-\mathrm{HNO}_{3}-\mathrm{HClO}_{4}$; As for total $\mathrm{Hg}$, it was digested by a double channel Atomic Fluorescence Spectrometer with the digestion of $\mathrm{HNO}-\mathrm{HCl}$ bathing in the hot water. We use reagent blanks and standard reference in the whole analysis procedure for quality assurance and quality control, and the recovery ranges of the trace elements were from 90 to $110 \%$ [31]. 


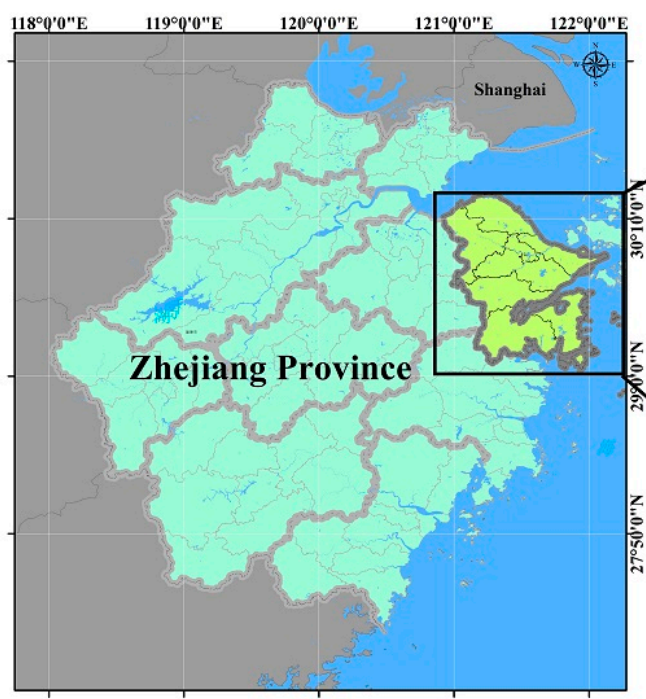

a. The location of study area

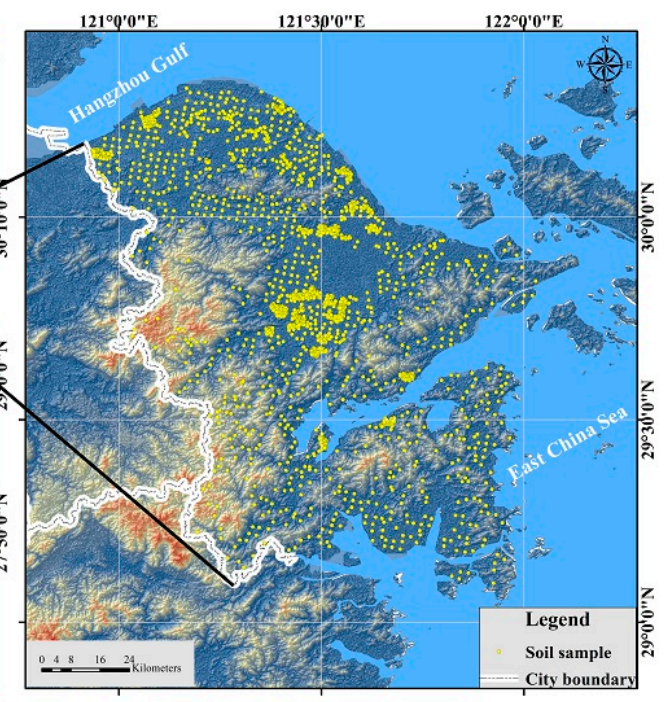

b. The distribution of sampling points

Figure 1. Maps showing the location of the study area (a) and the distribution of sampling points (b).

\subsection{Auxiliary Variables Data}

The study area is known for its industrial prosperity, and its total industrial output value accounted for $45 \%$ of its whole economic output value in 2016. We obtained information of 48,206 industrial enterprises in the study area from Baidu Map POI (Point of Interest) data that listed all the industrial enterprises in 2016. We removed data for irrelevant non-industrial enterprises, and then classified the industrial enterprises into four categories: textiles, metal products, chemical products, and other industries. We obtained information about the soil parent material in the study area from a 1:20,000 soil map of Zhejiang Province (1990) [32] and the soil types from a 1:50,000 Map of Chinese Soil (1990) published by the National Soil Survey of China, respectively.

\subsection{Single Pollution Index (SPI)}

We used the single pollution index (SPI) to assess the pollution degree of trace elements contents in soil. The SPI is calculated as follows:

$$
P_{i}=\frac{C_{i}}{S_{i}}
$$

where $P_{i}$ is the SPI of trace element $i$ in soil, $C_{i}$ is the test value of trace element $i$, and $S_{i}$ is the regulation value in China [33]. When $P_{i}$ is less than or equal to 1 , the content of the soil trace element $i$ is within a safe range, while when $P_{i}$ is within the range of 1 to 2 , the content of the soil trace element $i$ slightly exceeds the standard value; when $P_{i}$ is within the range of 2 to 3 , soils could be moderately contaminated by trace element $i$; and when $P_{i}$ is greater than 3 , soils could be severely contaminated by trace element $i$.

\subsection{Ordinary Kriging $(O K)$}

We used the widely-used ordinary kriging (OK) model to show the spatial variations of each soil trace element across the study area. The equation for this model is as follows [34,35]:

$$
Z^{*}\left(x_{0}\right)=\sum_{i=1}^{n} \varphi_{i} Z\left(x_{i}\right)
$$

where $Z^{*}\left(x_{0}\right)$ is the linear prediction value while $Z\left(x_{i}\right)$ is the observed value. $n$ and $i$ denote the quantities of observed and predicted samples, respectively, and $\varphi_{i}$ is the optimal weight value that results in an unbiased prediction with the minimum variance. 


\subsection{Principle Component Analysis (PCA)}

We distinguished different groups of trace elements with PCA. This tool uses an orthogonal transformation to convert a set of observations of possibly correlated variables into a set of values of linearly uncorrelated variables. We then used non-transformed data to calculate the correlation matrix, performed an orthogonal rotation based on the Kaiser Standard, and extracted factors with eigenvalues greater than 1 after a maximum of 25 iterations [36].

\subsection{Finite Mixture Distribution Model (FMDM)}

For a random variable $x$, if a mixture distribution consists of $\mathrm{m}$ components and the distribution of the $i$ th individual component is determined by a specific probability density function (pdf) $f_{i}(x)$, then the general $\operatorname{pdf} f(x)$ for the mixture distribution can be expressed as [27,37]:

$$
\begin{gathered}
f(x)=\sum_{i=1}^{m} \pi_{i} f_{i}(x)=\pi_{1} f_{1}(x)+\ldots+\pi_{m} f_{m}(x) \\
\sum_{i=1}^{m} \pi_{i}=1\left(0 \leq \pi_{i} \leq 1\right)
\end{gathered}
$$

where $\pi_{i}$ denotes the mixed weights of every sub-distribution.

Many natural processes follow a normal distribution or a log-normal distribution. Here, we used a log-normal distribution as the pdf to describe the trace element content of soils from different sources [38], as follows:

$$
f_{i}\left(x \mu_{m}, \sigma_{m}\right)=\frac{1}{\sqrt{2 \pi} \sigma_{m} x} e^{-\frac{\left(\ln x-\mu_{m}\right)^{2}}{2 \sigma_{m}{ }^{2}}}, x>0
$$

where $\mu_{m}$ and $\sigma_{m}$ represent the mean and standard deviation of every sub-distribution, which can be obtained using an expectation maximization algorithm [39]. We then used the Chi-square goodness-of-fit test to test the null hypothesis $H_{0}$ to confirm that the assumed model was consistent with the observed distribution. The cut-off value between the $i$ th and $(i+1)$ components can be calculated after the above parameters have been determined, as follows:

$$
\pi_{i} \int_{a_{0}}^{+\infty} f_{i}(x) d x=\pi_{i+1} \int_{-\infty}^{a_{0}} f_{i+1}(x) d x
$$

\subsection{Data Analysis}

In this study, we did all the statistical analyses with Microsoft Excel 2016 (Office 2016, Redmond, WA, USA). We used the geostatistical analyst tool in ArcGIS 10.2 (ESRI, ArcGIS10.2, Redlands, CA, USA) for the kriging interpolation. Principal component analysis of the seven soil trace elements was carried out with the psych package of R3.4.2 [40] and the FMDM was done in R3.4.2 using Mclust package [41].

\section{Results and Discussion}

\subsection{Summary Statistical Analysis of Soil Trace Elements}

The average concentrations of $\mathrm{Cr}, \mathrm{Cd}, \mathrm{Hg}, \mathrm{As}, \mathrm{Cu}, \mathrm{Zn}$, and $\mathrm{Ni}$ in the study area were $67.72,0.197$, $0.288,6.58,34.77,110.67$, and $29.22 \mathrm{mg} / \mathrm{kg}$, respectively (Table 1). Apart from $\mathrm{Cr}$, the average values of the trace elements were higher than the background values; the averages of $\mathrm{Hg}, \mathrm{Cd}, \mathrm{Zn}$, and $\mathrm{Cu}$ were much higher than the background values which suggest that these trace elements may have been affected by human activities [26].

The coefficient of variation (CV) reflects the degree of dispersion of the sample data [42]. The CV values of the soil trace elements in the study area were ranked as follows: $\mathrm{Hg}(104.55 \%)>\mathrm{Ni}(56.96 \%)>$ 
$\mathrm{Cd}(50.68 \%)>\mathrm{Cu}(47.99 \%)>\mathrm{Cr}(43.41 \%)>\mathrm{As}(40.33 \%)>\mathrm{Zn}(33.0 \%)$. The uneven distribution of $\mathrm{Hg}$ reflects anthropogenic impacts, and the other trace elements also showed different degrees of variability.

Table 1. Summary statistics for trace elements in topsoil $(\mathrm{mg} / \mathrm{kg})[43]$.

\begin{tabular}{cccccccc}
\hline Element & $\mathbf{C r}$ & $\mathbf{C d}$ & $\mathbf{H g}$ & $\mathbf{A s}$ & $\mathbf{C u}$ & $\mathbf{Z n}$ & $\mathbf{N i}$ \\
\hline Mean & 67.72 & 0.197 & 0.288 & 6.58 & 34.77 & 110.67 & 29.22 \\
Median & 69.7 & 0.18 & 0.19 & 6.26 & 33 & 106 & 29.8 \\
SD & 29.4 & 0.099 & 0.301 & 2.65 & 16.69 & 36.52 & 16.64 \\
CV & $43.41 \%$ & $50.68 \%$ & $104.55 \%$ & $40.33 \%$ & $47.99 \%$ & $33.00 \%$ & $56.96 \%$ \\
Range & $6.04-326.0$ & $0.03-1.84$ & $0.02-2.26$ & $0.87-19.2$ & $4.28-315.0$ & $34.30-714.0$ & $2.89-293.0$ \\
Background Value & 68.7 & 0.157 & 0.11 & 6.23 & 29.2 & 89.9 & 26.3 \\
Background Interval & $43.0-94.4$ & $0.101-0.213$ & $0.048-0.231$ & $3.94-8.52$ & $9.7-48.6$ & $51.6-128.2$ & $20.6-32.1$ \\
\hline
\end{tabular}

SD: standard deviation; CV: coefficient of variation.

\subsection{Analysis of Auxiliary Variable Data}

As shown in previous studies, industrial pollution is a major source of trace element pollution in the soil [44-46]. Trace elements in industrial waste water, waste gas, and waste residues enter the soil via sewage irrigation, garbage dumping, and atmospheric deposition, resulting in high trace element concentrations in the soil [46-48]. Analysis of the density of all the industrial enterprises (Figure 2) in the study area shows that the density was highest for the metal product enterprises, followed by chemical product enterprises, then textiles, and was lowest for other enterprises, and that most enterprises were clustered around the urban city areas.

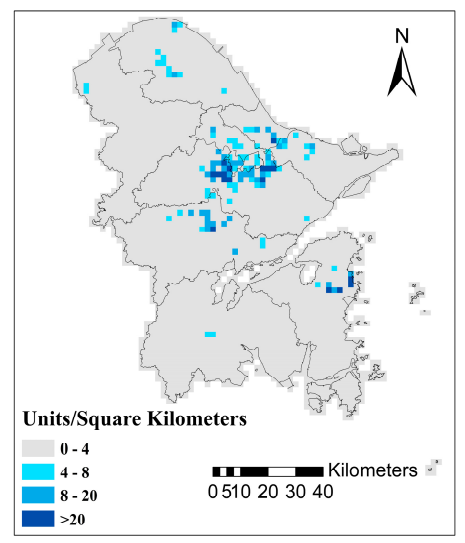

a

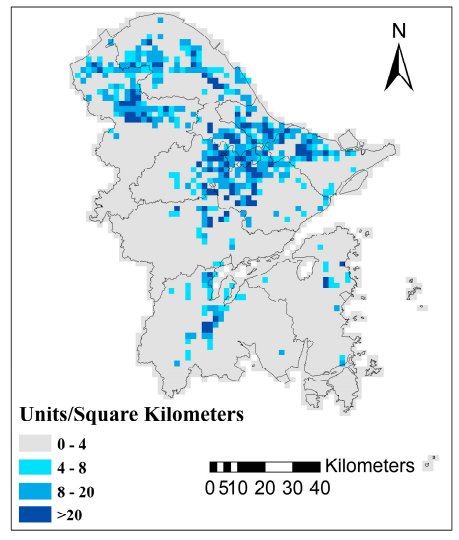

c

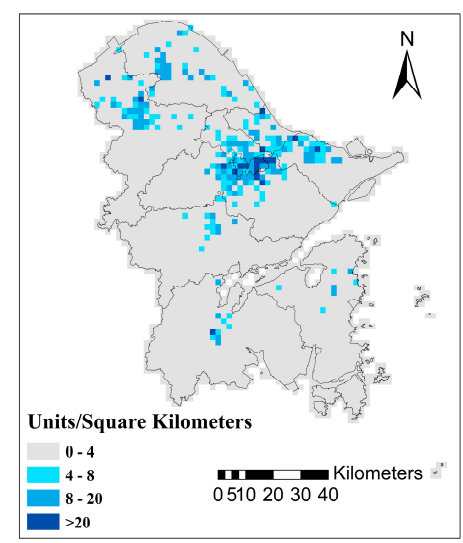

b

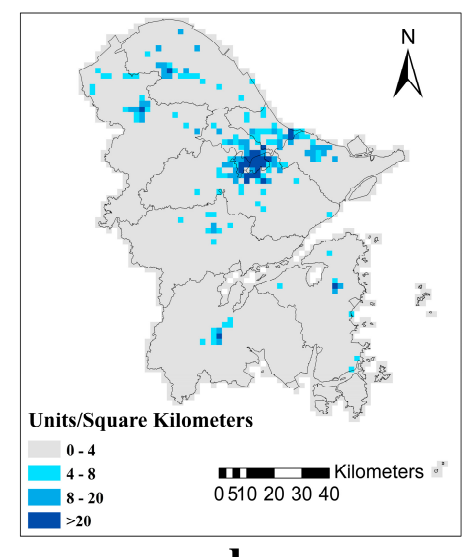

d

Figure 2. The density maps of (a) textile enterprises; (b) chemical product enterprises; (c) metal product enterprises; and (d) other enterprises in the study area (Units $/ \mathrm{km}^{2}$ ). 
As Table 2 indicates, the $\mathrm{Cr}$ and $\mathrm{Ni}$ concentrations increased as the quantity of textile enterprises increased, reflecting the quantitative impacts of the textile industry on these two trace elements. Similarly, chemical product enterprises influenced the concentrations of $\mathrm{Hg}, \mathrm{Cu}, \mathrm{Zn}$, and $\mathrm{Ni}$; metal product enterprises influenced the concentrations of $\mathrm{Cr}, \mathrm{Hg}, \mathrm{Cu}$, and $\mathrm{Zn}$, and other enterprises influenced the $\mathrm{Ni}, \mathrm{Hg}$, and $\mathrm{Cu}$ concentrations. In general, as the total number of all enterprises increased, the contents of all seven trace elements increased dramatically, which shows that industrial activities were a major contributor to trace elements in soils.

Table 2. Average trace elements from different numbers of the different enterprises $(\mathrm{mg} / \mathrm{kg})$.

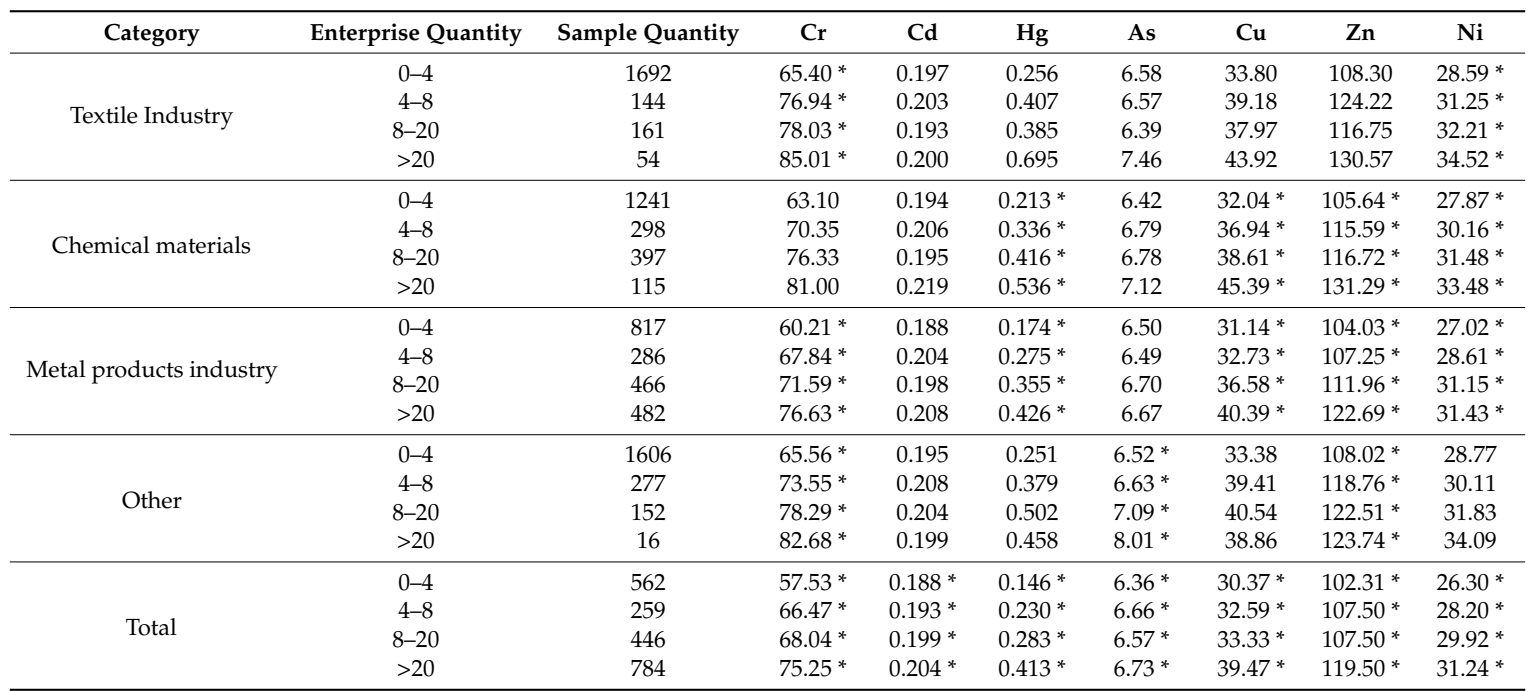

* indicates that the value of different trace elements increased as the number of the different industries increased, which shows the quantitative impacts of industries on trace elements.

Rhyolitic, tuffaceous residual slope faces dominated the parent materials (Table 3 and Figure 3a) in the study area. Lakes and marshes extended over large parts of the north-central part of the study area, while coastal sedimentary parent materials covered large areas of the northern and southern parts. The main soil types (Table 4 and Figure 3 b) were divided into paddy, fluvo-aquic, red, coastal saline, skeletal, yellow, and purple soils. Paddy soils and red soils dominated the study area; red soils were distributed across the entire study area and paddy soils were mainly distributed over most of the central and northern parts. Fluvo-aquic and coastal saline soils were mostly distributed in the northern coastal areas, and skeletal soils were distributed in the central and southern regions.

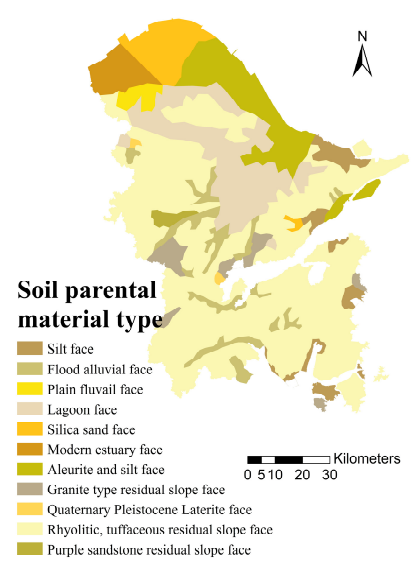

a

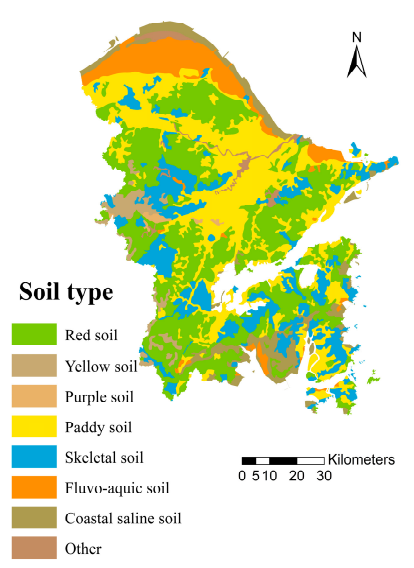

$\mathbf{b}$

Figure 3. The distribution of the (a) soil parent materials and (b) soil types in the study area. 
Table 3. Average concentrations of trace elements in soils from different parent materials (mg/kg).

\begin{tabular}{|c|c|c|c|c|c|c|c|c|c|c|}
\hline \multicolumn{2}{|c|}{ Soil Parental Materials Type } & \multirow{3}{*}{$\begin{array}{c}\text { Sample } \\
\text { Quantity }\end{array}$} & \multirow{3}{*}{$\begin{array}{c}\mathrm{Cr} \\
51.84 \\
67.73 * \\
\end{array}$} & \multirow{3}{*}{$\begin{array}{c}\mathbf{P b} \\
50.38^{*} \\
35.07\end{array}$} & \multirow{3}{*}{$\begin{array}{c}\text { Cd } \\
0.212 * \\
0.190 \\
\end{array}$} & \multirow{3}{*}{$\begin{array}{c}\mathbf{H g} \\
0.213 \\
0.236\end{array}$} & \multirow{3}{*}{$\begin{array}{c}\text { As } \\
4.86 \\
6.37\end{array}$} & \multirow{3}{*}{$\begin{array}{c}\mathrm{Cu} \\
29.25 \\
42.25^{*} \\
\end{array}$} & \multirow{3}{*}{$\begin{array}{c}\text { Zn } \\
111.35 \text { * } \\
120.90^{*} \\
\end{array}$} & \multirow{3}{*}{$\begin{array}{c}\mathbf{N i} \\
23.58 \\
29.70 * \\
\end{array}$} \\
\hline Flooding parental & Flood alluvial face & & & & & & & & & \\
\hline material & Plain fluvial face & & & & & & & & & \\
\hline $\begin{array}{l}\text { Estuary alluvial } \\
\text { sediment }\end{array}$ & Modern estuary face & 149 & 61.79 & 34.00 & 0.199 & 0.210 & 6.21 & 31.19 & 90.98 & 28.23 \\
\hline \multirow{4}{*}{$\begin{array}{l}\text { Stumpy parental } \\
\text { material }\end{array}$} & $\begin{array}{l}\text { Granite type residual } \\
\text { slope face }\end{array}$ & 25 & 30.36 & $46.67^{*}$ & 0.205 & 0.108 & 3.77 & 20.64 & 99.54 & 12.09 \\
\hline & $\begin{array}{c}\text { Quaternary Pleistocene } \\
\text { Laterite face }\end{array}$ & 6 & 62.30 & $48.40 *$ & $0.475 *$ & 0.171 & 3.67 & 28.50 & 95.32 & 13.75 \\
\hline & $\begin{array}{l}\text { Rhyolitic, tuffaceous } \\
\text { residual slope face }\end{array}$ & 586 & 59.41 & $43.93 *$ & 0.185 & 0.194 & $6.64 *$ & 31.86 & 109.53 & 26.48 \\
\hline & $\begin{array}{l}\text { Purple sandstone } \\
\text { residual slope face }\end{array}$ & 9 & 46.80 & 31.54 & 0.112 & 0.116 & 4.82 & 25.53 & 88.18 & 17.26 \\
\hline $\begin{array}{c}\text { Lacustrine parent } \\
\text { material }\end{array}$ & Lagoon face & 655 & $77.10^{*}$ & $51.15^{*}$ & $0.206^{*}$ & $0.496^{*}$ & 6.40 & $38.99 *$ & 118.80 * & $30.60 *$ \\
\hline \multirow{3}{*}{$\begin{array}{l}\text { Coastal deposition } \\
\text { parental material }\end{array}$} & Silica sand face & 168 & 63.44 & 28.64 & 0.196 & 0.136 & 6.27 & 30.73 & 94.28 & 29.20 \\
\hline & Aleurite and silt face & 293 & $76.58 *$ & 35.19 & 0.194 & 0.209 & $7.97 *$ & $38.04 *$ & 114.21 * & $35.12 *$ \\
\hline & Silt face & 35 & $82.07 *$ & 37.39 & 0.188 & 0.145 & $8.76^{*}$ & 36.67 & 117.93 * & $38.02 *$ \\
\hline
\end{tabular}

* indicates a significant level of different trace elements from different soil parental materials.

Table 4. Average concentrations of trace elements in the different soil types $(\mathrm{mg} / \mathrm{kg})$.

\begin{tabular}{ccccccccc}
\hline Soil Types & Sample Quantity & $\mathbf{C r}$ & $\mathbf{C d}$ & $\mathbf{H g}$ & $\mathbf{A s}$ & $\mathbf{C u}$ & $\mathbf{Z n}$ & $\mathbf{N i}$ \\
\hline Coastal saline soil & 118 & $70.40^{*}$ & 0.168 & 0.100 & $8.71^{*}$ & $36.39 *$ & 104.53 & $34.39 *$ \\
Fluvo-aquic soil & 370 & 67.07 & 0.195 & 0.155 & $6.83^{*}$ & 32.98 & 97.36 & $31.20^{*}$ \\
Skeletal soil & 155 & 60.31 & 0.186 & $0.458^{*}$ & 5.74 & 34.22 & 109.54 & 24.08 \\
Red soil & 278 & 54.68 & $0.201^{*}$ & 0.254 & 5.39 & 31.72 & 107.54 & 22.92 \\
Yellow soil & 8 & 57.71 & 0.188 & 0.206 & 5.17 & 17.18 & 90.86 & 16.07 \\
Paddy soil & 1099 & $72.08^{*}$ & $0.203^{*}$ & $0.341 *$ & $6.72 *$ & $36.32 *$ & $117.30^{*}$ & $30.42^{*}$ \\
Purple soil & 5 & 61.26 & 0.121 & 0.117 & 6.09 & 27.44 & 87.14 & 22.53 \\
Other & 18 & $68.72 *$ & 0.159 & 0.212 & 6.18 & 28.13 & 92.38 & $30.18^{*}$ \\
\hline
\end{tabular}

* indicates a significant level of different trace elements in different soil types.

\subsection{Assessment of Trace Element Pollution}

The SPI values showed that, apart from $\mathrm{Hg}$, the soils were only slightly polluted by trace elements. The soils from more than $90 \%$ of the sampling points had $P_{i}$ values less than or equal to 1 (Table 5), which indicates that the other 6 trace elements did not pose much risk to the environment or ecology. There are obvious signs of $\mathrm{Hg}$ contamination in the study area and, with $18.97 \%, 6.05 \%$, and $5.70 \%$ of the soils lightly, moderately, and severely polluted, respectively, around $30 \%$ of the soils from the study area were adversely impacted by $\mathrm{Hg}$.

Table 5. Values of the SPI for different trace elements.

\begin{tabular}{ccccccccc}
\hline \multirow{2}{*}{ Element } & \multicolumn{2}{c}{$\boldsymbol{P}_{\boldsymbol{i}} \leq \mathbf{1}$} & \multicolumn{2}{c}{$\mathbf{1 < \boldsymbol { P } _ { \boldsymbol { i } } \leq \mathbf { 2 }}$} & \multicolumn{2}{c}{$\mathbf{2 < \boldsymbol { P } _ { \boldsymbol { i } } \leq \mathbf { 3 }}$} & \multicolumn{2}{c}{$\boldsymbol{P}_{\boldsymbol{i}}>\mathbf{3}$} \\
\cline { 2 - 9 } & $\begin{array}{c}\text { Sample } \\
\text { Number }\end{array}$ & Proportion & $\begin{array}{c}\text { Sample } \\
\text { Number }\end{array}$ & Proportion & $\begin{array}{c}\text { Sample } \\
\text { Number }\end{array}$ & Proportion & $\begin{array}{c}\text { Sample } \\
\text { Number }\end{array}$ & Proportion \\
\hline $\mathrm{Cr}$ & 2036 & $99.27 \%$ & 14 & $0.68 \%$ & 1 & $0.05 \%$ & 0 & $0 \%$ \\
$\mathrm{Cd}$ & 1917 & $93.47 \%$ & 124 & $6.05 \%$ & 7 & $0.34 \%$ & 3 & $0.15 \%$ \\
$\mathrm{Hg}$ & 1421 & $69.28 \%$ & 389 & $18.97 \%$ & 124 & $6.05 \%$ & 117 & $5.70 \%$ \\
$\mathrm{As}$ & 2051 & $100 \%$ & 0 & $0 \%$ & 0 & $0 \%$ & 0 & $0 \%$ \\
$\mathrm{Cu}$ & 1975 & $96.29 \%$ & 73 & $3.56 \%$ & 2 & $0.10 \%$ & 1 & $0.05 \%$ \\
$\mathrm{Zn}$ & 2023 & $98.63 \%$ & 25 & $1.22 \%$ & 2 & $0.10 \%$ & 1 & $0.05 \%$ \\
$\mathrm{Ni}$ & 1897 & $92.49 \%$ & 137 & $6.68 \%$ & 7 & $0.34 \%$ & 10 & $0.49 \%$ \\
\hline
\end{tabular}




\subsection{Spatial Distribution of Soil Trace Elements}

The general spatial distribution of trace elements in soils in the study area is presented in Figure 4. $\mathrm{Cr}$, As, and Ni concentrations were highest in the central urban areas and the coastal areas (Figure $4 \mathrm{a}, \mathrm{d}, \mathrm{g}$ ). It is revealed by Table 3 that the main sources of $\mathrm{Cr}, \mathrm{As}$, and Ni were aleurite and silt face (with silt face as the dominant source in the coastal areas), and the fact that the concentrations of these trace elements were highest in the urban centers indicates that they were closely related to anthropogenic activities. As shown in Figure $4 \mathrm{~b}, \mathrm{f}$, areas with high $\mathrm{Cd}$ and $\mathrm{Zn}$ concentrations were relatively scattered and were mainly concentrated in the northern and central urban areas. The chemical industries probably influenced the $\mathrm{Cd}$ and $\mathrm{Zn}$ concentrations (Table 2). Concentrations of $\mathrm{Hg}$ and $\mathrm{Cu}$ were highest in the central parts of the urban areas (Figure $4 \mathrm{c}, \mathrm{f})$, and close to the metal and textile industries (Table 2).
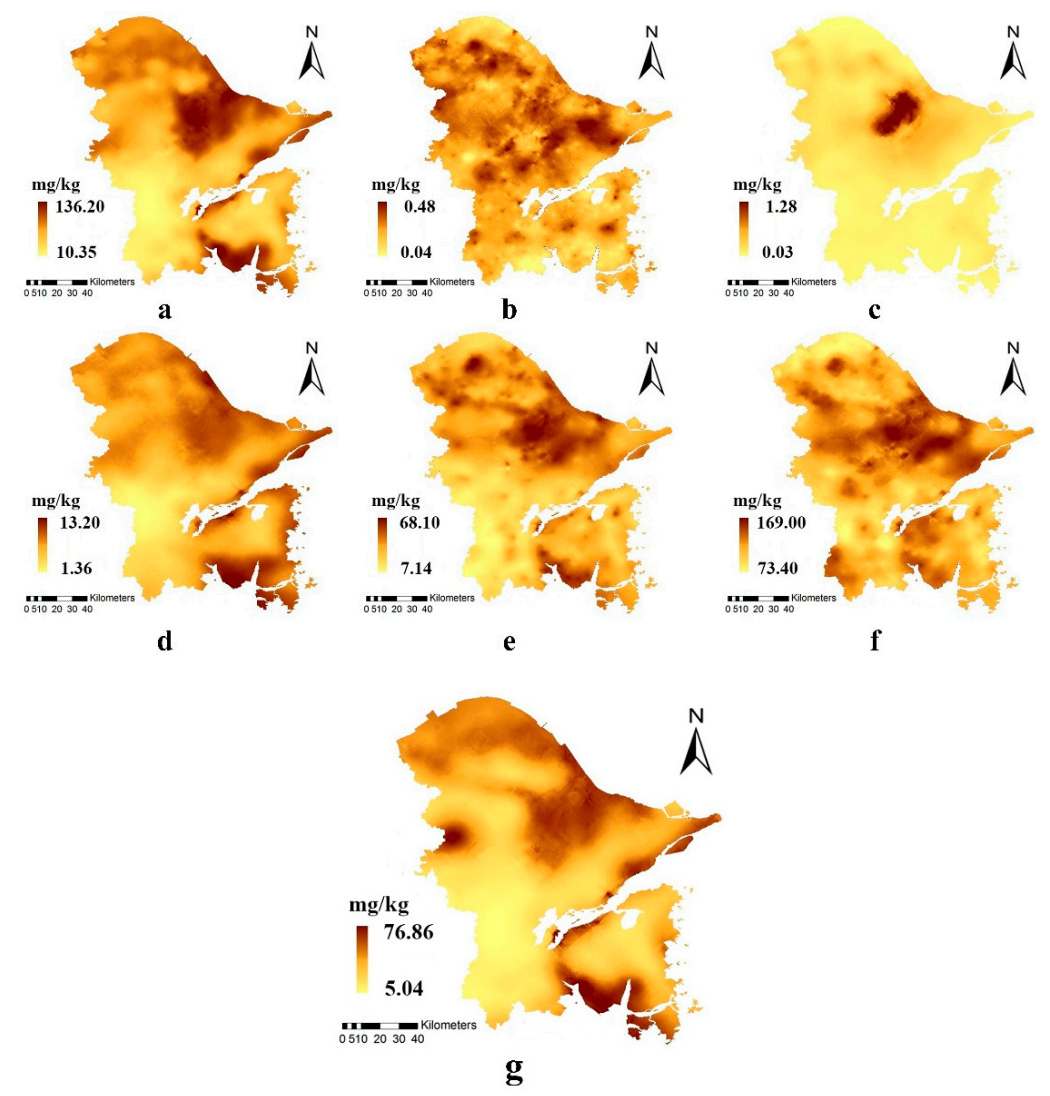

Figure 4. Spatial distributions of (a) $\mathrm{Cr}$; (b) $\mathrm{Cd}$; (c) $\mathrm{Hg}$; (d) $\mathrm{As}$; (e) $\mathrm{Cu}$; (f) $\mathrm{Zn}$; and (g) $\mathrm{Ni}$.

\subsection{Source Identification Based on PCA}

The Cattell's scree plot (Figure 5) shows that the seven trace elements fell into three main components, while the PCA (Table 6) results show that the cumulative contribution rate of the three main components was up to $70.0 \%$. The first principal component (PC1) contained three trace elements, $\mathrm{Cr}$, As, and $\mathrm{Ni}$; the second principal component (PC2) contained $\mathrm{Cd}, \mathrm{Cu}$, and $\mathrm{Zn}$, and the third component (PC3) represented Hg. PC1, PC2, and PC3 accounted for 30\%, 25\%, and 15\%, respectively.

The contribution of PC1 was up to $30 \%$ (Table 6), and had factor loadings of $0.88,0.73$, and 0.87 for $\mathrm{Cr}$, As, and $\mathrm{Ni}$, respectively. This suggests $\mathrm{Cr}$, As, and $\mathrm{Ni}$ had the same pollution source. The OK spatial interpolation map (Figure 6a) shows that PC1 gradually decreased from the coast to the inland area, where the high-value areas were mainly confined to the city centers, the northeast, and the southern coastal areas. This trend greatly matches previous spatial distribution analysis, so these trace elements were mainly from natural sources. 


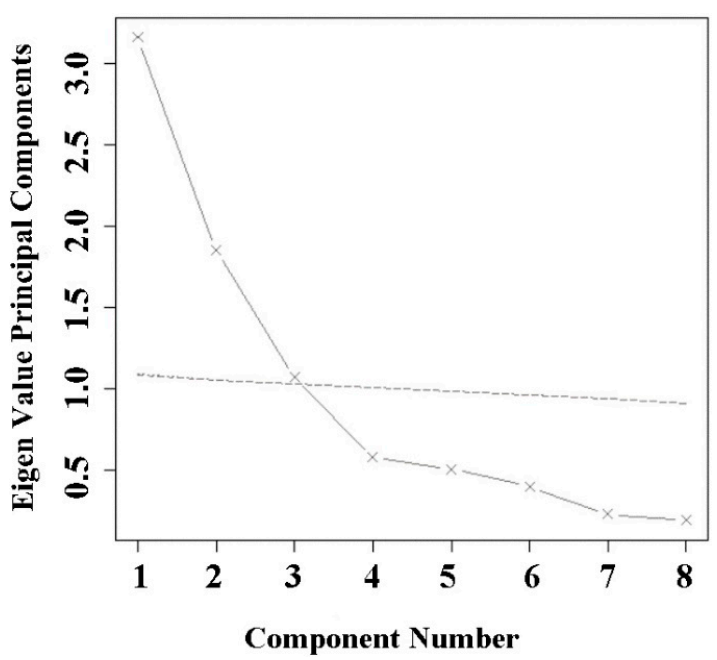

Figure 5. Cattell's scree plot (a parallel analysis of 100 simulations).

Table 6. PCA rotation matrix.

\begin{tabular}{ccccccc}
\hline \multirow{2}{*}{ Element } & \multicolumn{3}{c}{ Component Matrix } & \multicolumn{3}{c}{ Rotated Component Matrix } \\
\cline { 2 - 7 } & PC1 & PC2 & PC3 & PC1 (30\%) & PC2 (25\%) & PC3 (15\%) \\
\hline $\mathrm{Cr}$ & 0.82 & -0.39 & 0.06 & 0.88 & 0.18 & 0.15 \\
$\mathrm{Cd}$ & 0.34 & 0.73 & -0.23 & -0.20 & 0.81 & 0.04 \\
$\mathrm{Hg}$ & 0.40 & 0.28 & 0.53 & 0.12 & 0.26 & 0.67 \\
$\mathrm{As}$ & 0.57 & -0.47 & 0.03 & 0.73 & -0.01 & 0.04 \\
$\mathrm{Cu}$ & 0.81 & 0.27 & -0.14 & 0.45 & 0.72 & 0.12 \\
$\mathrm{Zn}$ & 0.72 & 0.44 & -0.20 & 0.28 & 0.82 & 0.10 \\
$\mathrm{Ni}$ & 0.75 & -0.46 & -0.10 & 0.87 & 0.14 & -0.03 \\
\hline
\end{tabular}

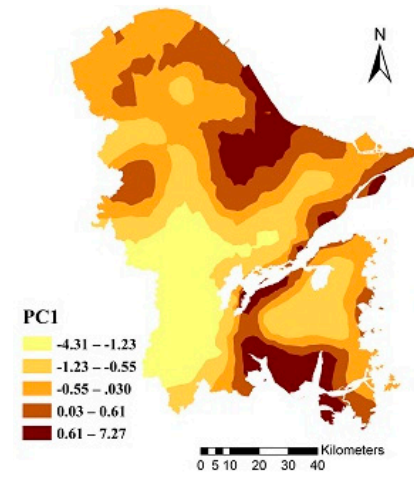

a

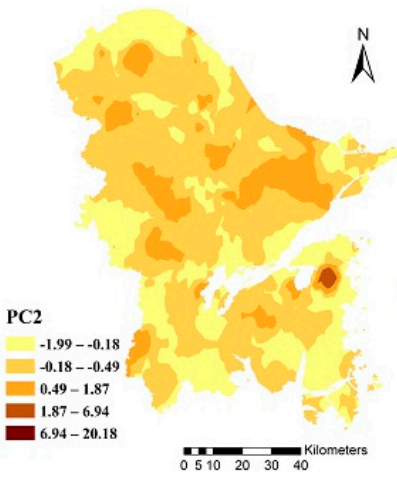

b

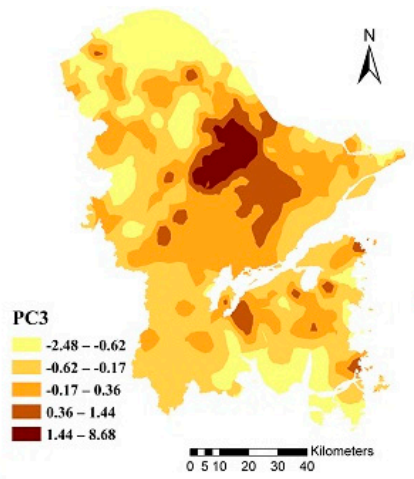

c

Figure 6. OK interpolation maps of (a) PC1; (b) PC2; (c) PC3.

The contribution of PC2 was $25 \%$ (Table 6); $\mathrm{Cd}, \mathrm{Cu}$, and $\mathrm{Zn}$ had factor loadings of $0.81,0.72$, and 0.82 , respectively, which suggest a common pollution source. Alternatively, because $\mathrm{Zn}$ and $\mathrm{Cu}$ contributed as much as 0.45 and 0.28 to the first principal component, $\mathrm{Zn}$ and $\mathrm{Cu}$ may have shared the sources for PC1. The areas with high values for PC2 (Figure 6b) were scattered across the study area, with clusters in the northwestern, southern, and central urban parts of the study area. This suggests that PC2 represented mixed pollutant sources, such as traffic exhaust gases, domestic garbage, and agricultural inputs. 
The contribution rate from PC3 was 15\%, and the factor loading of $\mathrm{Hg}$ was 0.67 . The OK interpolation map of PC3 (Figure 6c) shows that the areas with high values were mainly distributed in the central parts of the urban areas, which perfectly matches the spatial distribution map. This shows that industrial pollution was the main source of $\mathrm{Hg}$.

\subsection{Source Identification Based on FMDM}

In general, the FMDM results showed that $\mathrm{Cr}, \mathrm{As}, \mathrm{Hg}$, and $\mathrm{Ni}$ conformed to the log-normal mixture distribution; $\mathrm{Cd}, \mathrm{Cu}$, and $\mathrm{Zn}$ conformed to the log-normal distribution, and the seven trace elements passed the significance level test $(p>0.05)$.

$\mathrm{Cd}, \mathrm{Cu}$, and $\mathrm{Zn}$ fitted the single log-normal distribution model as shown in Figure $7 \mathrm{~b}, \mathrm{e}, \mathrm{f}$. The FMDM was not able to clearly identify whether these trace elements had natural or anthropogenic sources, because their sources did not significantly differ throughout the entire study area; the modelled average concentrations were higher than the soil background values, which suggests unnatural sources. So, these three trace elements may have derived in parts from human activities that generate multiple pollutants, including urban development, population increases, domestic garbage, traffic pollution, and agricultural inputs.

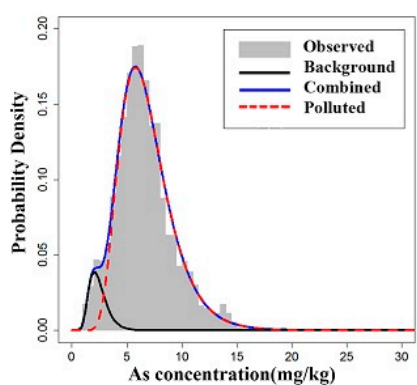

$\mathbf{a}$

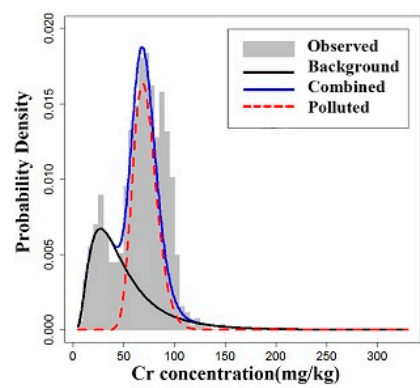

d

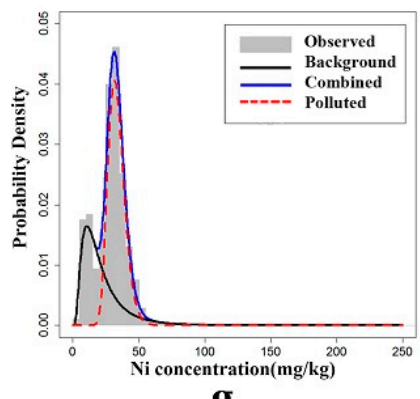

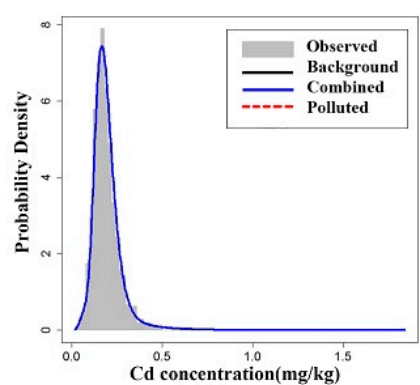

b

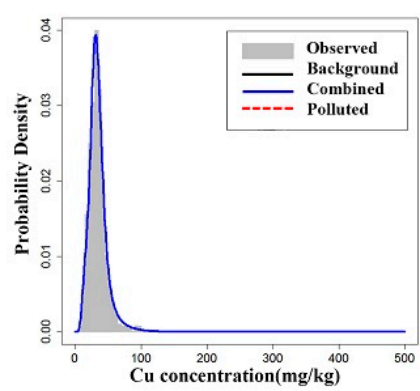

$\mathbf{e}$

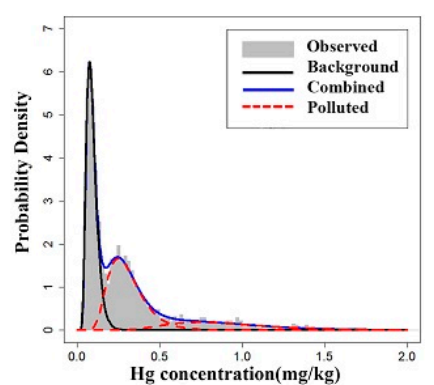

c

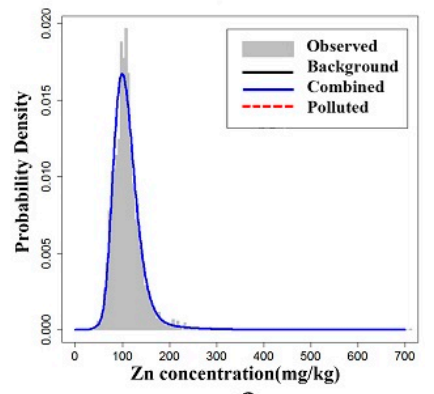

f

Figure 7. FMDM fit for (a) $\mathrm{Cr}$; (b) $\mathrm{Cd}$; (c) $\mathrm{Hg}$; (d) As; (e) $\mathrm{Cu}$; (f) $\mathrm{Zn}$; and (g) Ni.

The concentrations of $\mathrm{Cr}$, As, and Ni were all consistent with the double log-normal distribution model (Figure $7 \mathrm{a}, \mathrm{d}, \mathrm{g}$ ), and should fall within the natural and anthropogenic distributions in theory. As shown in Table 7, the means of $\mathrm{Cr}$, As, and $\mathrm{Ni}$ from the natural distribution were lower than the 
soil background values (Table 7). The means of the anthropogenic distributions exceeded the soil background values, but were still within the ranges of the background values (Table 1); the FMDM therefore identified two sub-distributions as a low-value natural distribution and a high-value natural and anthropogenic mixed distribution. This suggests that $\mathrm{Cr}$, As, and $\mathrm{Ni}$ may have been influenced by anthropogenic activities, but their impacts were not much more than the impacts from a high-value natural background. In such cases, the effects of these trace elements from anthropogenic sources would not be apparent.

Table 7. FMDM parameters and thresholds.

\begin{tabular}{|c|c|c|c|c|c|c|c|c|c|}
\hline Elements & Class & Proportion \% & $\begin{array}{c}\text { Mean } \\
(\mathrm{mg} / \mathrm{kg})\end{array}$ & $\begin{array}{c}\text { STD } \\
(\mathrm{mg} / \mathrm{kg})\end{array}$ & Freedom & $x^{2}$ & $p$ & $\begin{array}{l}\text { Cutoff Value } \\
\text { (mg/kg) }\end{array}$ & $\begin{array}{l}\text { Background } \\
\text { Values }\end{array}$ \\
\hline $\mathrm{Cr}$ & 2 & $\begin{array}{l}35.79 \% \\
64.21 \%\end{array}$ & $\begin{array}{l}49.51 \\
77.54\end{array}$ & $\begin{array}{c}1231.02 \\
226.39\end{array}$ & 52 & 51.47 & 0.15 & 52.49 & 68.7 \\
\hline $\mathrm{Cd}$ & 1 & $100 \%$ & 0.18 & 0.006 & 45 & 48.06 & 0.35 & - & 0.157 \\
\hline $\mathrm{Hg}$ & 3 & $\begin{array}{l}45.35 \% \\
41.21 \% \\
13.44 \%\end{array}$ & $\begin{array}{l}0.09 \\
0.30 \\
0.91\end{array}$ & $\begin{array}{c}0.001 \\
0.002 \\
0.12\end{array}$ & 20 & 16.27 & 0.7 & $\begin{array}{l}0.156 \\
0.566\end{array}$ & 0.11 \\
\hline As & 2 & $\begin{array}{c}7.28 \% \\
92.72 \%\end{array}$ & $\begin{array}{l}2.74 \\
6.85\end{array}$ & $\begin{array}{l}0.75 \\
6.05\end{array}$ & 41 & 51.81 & 0.12 & 2.85 & 6.23 \\
\hline $\mathrm{Cu}$ & 1 & $100 \%$ & 34.65 & 206.12 & 55 & 59.05 & 0.33 & - & 29.2 \\
\hline $\mathrm{Zn}$ & 1 & $100 \%$ & 127.80 & 3857.11 & 68 & 53.54 & 0.09 & - & 89.9 \\
\hline $\mathrm{Ni}$ & 2 & $\begin{array}{l}38.51 \% \\
61.49 \%\end{array}$ & $\begin{array}{c}21.8 \\
31.29\end{array}$ & $\begin{array}{l}290.52 \\
39.94\end{array}$ & 30 & 28.76 & 0.53 & 22.77 & 26.3 \\
\hline
\end{tabular}

STD: standard deviations of log-normal distribution; $\chi^{2}$ : Chi-square goodness-of-fit statistics. $p$ means that the estimated model is consistent with the observed distribution; when $p 0.05, H_{0}$ is rejected.

The Hg concentrations fit the triple log-normal distribution mode, as shown in Table 7 and Figure 7c. A natural distribution and two anthropogenically-influenced distributions were identified. The modelled mean of natural distribution was below the soil background value, and the modelled means of both anthropogenically-influenced distributions significantly exceeded the soil background value and its maximum range (Table 1), showing that anthropogenic industrial activities were a major influence on the content of $\mathrm{Hg}$ in soils in the study area.

\section{Conclusions}

Source identification and apportionment of soil trace elements have always been important prerequisites for treating trace element-contaminated soils and preventing further contamination. In this study, we quantitatively identified the sources of seven trace elements in the Yangtze River Delta using PCA and FMDM. Our results showed that $\mathrm{Cr}$, As, and Ni in soil were mainly from natural sources through weathering of parent materials; $\mathrm{Cd}, \mathrm{Cu}$, and $\mathrm{Zn}$ were mainly from multiple mixed pollution sources, such as traffic pollutants, domestic garbage, and agricultural inputs, and $\mathrm{Hg}$ was mainly from industrial waste and discharge. Our study can efficiently provide valuable information for policy makers and administrators on trace elements contamination.

Author Contributions: Conceptualization, Y.L., J.W., Z.S.; Methodology, S.S., J.W.; Software, J.W., S.S.; Validation, S.S., B.H. and Y.L.; Formal Analysis, B.H., Z.F. and G.L.; Investigation, B.H., J.W., Z.F.; Resources, B.J.; Data Curation, S.S., G.L. and Y.Z.; Writing-Original Draft Preparation, S.S., B.H.; Writing-Review \& Editing, S.S., B.H. and Y.L.; Visualization, S.S. and Z.F.; Supervision, Z.S., Y.L. and B.H.; Project Administration, Y.L.; Funding Acquisition, Z.S.

Funding: This research was funded by Key Research and Development Project of Zhejiang Province (2015C02011), the National Key Research and Development Program of China (2016YFD0201200) and the National Natural Science Foundation of China (41771244). 
Acknowledgments: We acknowledge the support received by Bifeng Hu from the Chinese Scholarship Council (under grant agreement No. 201706320317) for 3 years' Ph.D. study in INRA and Orléans University. We also thank Zongzheng Liang for his help in the data processing.

Conflicts of Interest: The authors declare no conflict of interest. The founding sponsors had no role in the design of the study; in the collection, analyses, or interpretation of data; in the writing of the manuscript, and in the decision to publish the results.

\section{References}

1. Arrouays, D.; Saby, N.P.A.; Thioulouse, J.; Jolivet, C.; Boulonne, L.; Ratié, C. Large trends in French topsoil characteristics are revealed by spatially constrained multivariate analysis. Geoderma 2011, 161, 107-114. [CrossRef]

2. Lequy, E.; Saby, N.P.A.; Ilyin, I.; Bourin, A.; Sauvage, S.; Leblond, S. Spatial analysis of trace elements in a moss bio-monitoring data over France by accounting for source, protocol and environmental parameters. Sci. Total Environ. 2017, 590-591, 602-610. [CrossRef] [PubMed]

3. Marchant, B.P.; Saby, N.P.A.; Arrouays, D. A survey of topsoil arsenic and mercury concentrations across France. Chemosphere 2017, 181, 635-644. [CrossRef] [PubMed]

4. Hu, B.F.; Zhao, R.Y.; Chen, S.C.; Zhou, Y.; Jin, B.; Li, Y.; Shi, Z. Heavy Metal Pollution Delineation Based on Uncertainty in a Coastal Industrial City in the Yangtze River Delta, China. Int. J. Environ. Res. Public Health 2018, 15, 710. [CrossRef] [PubMed]

5. Shi, T.Z.; Guo, L.; Chen, Y.Y.; Wang, W.X.; Shi, Z.; Li, Q.Q.; Wu, G.F. Proximal and remote sensing techniques for mapping of soil contamination with heavy metals. Appl. Spectrosc. Rev. 2018, 3. [CrossRef]

6. Hu, B.F.; Wang, J.Y.; Jin, B.; Li, Y.; Shi, Z. Assessment of the potential health risks of heavy metals in soils in a coastal industrial region of the Yangtze River Delta. Environ. Sci. Pollut. Res. 2017, 24, 19816-19826. [CrossRef] [PubMed]

7. Marchant, B.P.; Saby, N.P.A.; Lark, R.M.; Bellamy, P.H.; Jolivet, C.C.; Arrouays, D. Robust analysis of soil properties at the national scale: Cadmium content of French soils. Eur. J. Soil Sci. 2010, 61, 144-152. [CrossRef]

8. Lacarce, E.; Saby, N.P.A.; Martin, M.P.; Marchant, B.P.; Boulonne, L.; Meersmans, J.; Jolivet, C.; Bispo, A.; Arrouays, D. Mapping soil $\mathrm{Pb}$ stocks and availability in mainland France combining regression trees with robust geostatistics. Geoderma 2012, 170, 359-368. [CrossRef]

9. Schneider, A.R.; Morvan, X.; Saby, N.P.A.; Cancès, B.; Ponthieu, M.; Gommeaux, M.; Marin, B. Multivariate spatial analyses of the distribution and origin of trace and major elements in soils surrounding a secondary lead smelter. Environ. Sci. Pollut. Res. 2016, 23, 15164-15174. [CrossRef] [PubMed]

10. Rambeau, C.M.C.; Baize, D.; Saby, N.; Matera, V.; Adatte, T.; Foellmi, K.B. High Cadmium concentrations in Jurassic limestone as the cause for elevated cadmium levels in deriving soils: A case study in Lower Burgundy, France. Environ. Earth Sci. 2010, 61, 1573-1585. [CrossRef]

11. Marchant, B.P.; Saby, N.P.A.; Jolivet, C.C.; Arrouays, D.; Lark, R.M. Spatial prediction of soil properties with copulas. Geoderma 2011, 162, 327-334. [CrossRef]

12. Hu, B.F.; Wang, J.Y.; Fu, T.T.; Li, Y.; Shi, Z. Application of spatial analysis in soil heavy metal pollution. Chin. J. Soil Sci. 2017, 48, 11. (In Chinese)

13. Saby, N.P.A.; Thioulouse, J.; Jolivet, C.C.; Ratie, C.; Boulonne, L.; Bispo, A.; Arrouays, D. Multivariate analysis of the spatial patterns of 8 trace elements using the French soil monitoring network data. Sci. Total Environ. 2009, 407, 5644-5652. [CrossRef] [PubMed]

14. Cheng, H.F.; Hu, Y.N. Planning for sustainability in China's urban development: Status and challenges for Dongtan eco-city project. J. Environ. Monit. 2010, 12, 119-126. [CrossRef] [PubMed]

15. Zelenka, M.P.; Wilson, W.E.; Chow, J.C.; Lioy, P.J. A combined TTFA CMB receptor modeling approach and ITS application to air-pollution sources in China. Atmos. Environ. 1994, 28, 1425-1435. [CrossRef]

16. Krumal, K.; Mikuska, P.; Vecera, Z. Application of organic markers in identification of sources of organic aerosols. Chem. Listy 2012, 106, 95-103.

17. Li, P.Z.; Duan, X.L.; Cheng, H.G.; Lin, C.Y. Application of Lead stable isotopes to identification of environmental source. Environ. Sci. Technol. 2013, 36, 63-67.

18. Vedantham, R.; Landis, M.S.; Olson, D.; Pancras, J.P. Source identification of PM2.5 in Steubenville, Ohio Using a hybrid method for highly time-resolved Data. Environ. Sci. Technol. 2014, 48, 1718-1726. [CrossRef] [PubMed] 
19. Shaw, P.M.; Johns, R.B. The identification of organic input sources of sediments from the Santa-Catalina basin using factor-analysis. Org. Geochem. 1986, 10, 951-958. [CrossRef]

20. Kim, E.; Hopke, P.K. Source identifications of airborne fine particles using positive matrix factorization and US environmental protection agency positive matrix factorization. J. Air Waste Manag. Assoc. 2007, 57, 811-819. [CrossRef] [PubMed]

21. Qu, M.K.; Wang, Y.; Huang, B.; Zhao, Y.C. Source apportionment of soil heavy metals using robust absolute principal component scores-robust geographically weighted regression (RAPCS-RGWR) receptor model. Sci. Total Environ. 2018, 626, 203-210. [CrossRef] [PubMed]

22. Zhong, B.Q.; Liang, T.; Wang, L.Q.; Li, K.X. Applications of stochastic models and geostatistical analyses to study sources and spatial patterns of soil heavy metals in a metalliferous industrial district of China. Sci. Total Environ. 2014, 490, 422-434. [CrossRef] [PubMed]

23. Hu, B.F.; Chen, S.C.; Hu, J.; Xia, F.; Xu, J.; Li, Y.; Shi, Z. Application of portable XRF and VNIR sensors for rapid assessment of soil heavy metal pollution. PLoS ONE 2017, 12, e0172438. [CrossRef] [PubMed]

24. Critchley, F. Influence in Princepal Components-Analysis. Biometrika 1985, 72, 627-636. [CrossRef]

25. Parra, S.; Bravo, M.A.; Quiroz, W.; Moreno, T.; Karanasiou, A.; Font, O.; Vidal, V.; Cereceda-Balic, F. Source apportionment for contaminated soils using multivariate statistical methods. Chemom. Intell. Lab. Syst. 2014, 138, 127-132. [CrossRef]

26. Dong, R.Z.; Jia, Z.M.; Li, S.Y. Risk assessment and sources identification of soil heavy metals in a typical county of Chongqing municipality, Southwest China. Process Saf. Environ. Prot. 2018, 113, 275-281. [CrossRef]

27. Hu, Y.N.; Cheng, H.F. Application of Stochastic Models in Identification and Apportionment of Heavy Metal Pollution Sources in the Surface Soils of a Large-Scale Region. Environ. Sci. Technol. 2013, 47, 3752-3760. [CrossRef] [PubMed]

28. Lin, Y.P.; Chang, C.R.; Chu, H.J.; Cheng, B.Y. Identifying the spatial mixture distribution of bird diversity across urban and suburban areas in the metropolis: A case study in Taipei Basin of Taiwan. Landsc. Urban Plan. 2011, 102, 156-163. [CrossRef]

29. Chu, H.J.; Yu, H.L.; Kuo, Y.M. Identifying spatial mixture distributions of PM2.5 and PM10 in Taiwan during and after a dust storm. Atmos. Environ. 2012, 54, 728-737. [CrossRef]

30. Zhou, Y.; Biswas, A.; Ma, Z.Q.; Lu, Y.L.; Chen, Q.X.; Shi, Z. Revealing the scale-specific controls of soil organic matter at large scale in Northeast and North China Plain. Geoderma 2016, 271, 71-79. [CrossRef]

31. Hu, B.F.; Jia, X.L.; Hu, J.; Xu, D.Y.; Xia, F.; Li, Y. Assessment of Heavy Metal Pollution and Health Risks in the Soil-Plant-Human System in. the Yangtze River Delta, China. Int. J. Environ. Res. Public Health. 2017, 14, 1042. [CrossRef] [PubMed]

32. Wang, S.F.; Li, R.A.; Ye, Z.J. Zhejiang Soil, 2nd ed.; Yu, Z.Y., Yan, X.Z., Wei, X.F., Eds.; Zhejiang Science and Technology Press: Hangzhou, China, 1990; Volume 1, pp. 103-477, ISBN 7-5341-0599-4. (In Chinese)

33. China National Environmental Protection Agency (CEPA). Environmental Quality Standard for Soils; Report No. GB15618-1995; China National Environmental Protection Agency: Beijing, China, 1995. (In Chinese)

34. Cressie, N. Spatial prediction and ordinary kriging. Math. Geol. 1988, 20, 405-421. [CrossRef]

35. Armstrong, M.; Boufassa, A. Comparing the robustness of ordinary kriging and lognormal kriging: Outlier Resistance. Math. Geol. 1988, 20, 447-457. [CrossRef]

36. Wold, S.; Esbensen, K.; Geladi, P. Principal Component Analysis. Chemom. Intell. Lab. Syst. 1987, 2, 37-52. [CrossRef]

37. Zhi, Y.Y.; Li, P.; Shi, J.C.; Zeng, L.Z.; Wu, L.S. Source identification and apportionment of soil cadmium in cropland of Eastern China: A combined approach of models and geographic information system. J. Soils Sediments 2015, 16, 467-475. [CrossRef]

38. Lin, Y.P.; Zhao, Y.; Hu, G.R.; Su, G.M. Application of multivariate statistics in source analysis of heavy metal pollution in soil. Earth Environ. 2011, 39, 6. (In Chinese)

39. Batzoglou, C. What is the expectation maximization algorithm? Comput. Biol. 2008, 26, 3.

40. R Development Core Team. R: A Language and Environment for Statistical Computing; R Foundation for Statistical Computing: Vienna, Australia, 2009; Available online: http:/ / www.R-project.org (accessed on 10 February 2015).

41. Fraley, C.; Raftery, A.E. Enhanced model-based clustering, density estimation, and discriminant analysis software: MCLUST. J. Classif. 2003, 20, 263-286. [CrossRef] 
42. Brock, J.E. Variation of coefficients of simultaneous linear equation. Q. Appl. Math. 1953, 11, $234-240$. [CrossRef]

43. Wang, Q.H.; Dong, Y.X.; Zhou, G.H.; Zheng, W. Soil Geochemistry Standard. Value and Environmental Background Value of Zhejiang Province. J. Ecol. Rural Environ. 2007, 23, 8. (In Chinese)

44. Cheng, J.L.; Shi, Z.; Li, Y.; Yang, D.Z.; Li, H.Y.; Zhu, Y.W. Assessing environmental quality of agricultural soils using GIS and multivariate analysis in Zhejiang province, China. J. Environ. Sci.-China 2005, 19, 315-319.

45. Wu, X.; Pan, G. Distribution of heavy metals in urban soils different in function zone. Acta Pedologica Sin. 2005, 42, 513-517. (In Chinese)

46. De la Cueva, A.V.; Marchant, B.P.; Quintana, J.R.; de Santiago, A.; Lafuente, A.L.; Webster, R. Spatial variation of trace elements in the peri-urban soil of Madrid. J. Soils Sediments. 2014, 14, 78-88. [CrossRef]

47. Yuan, Y.; Bian, J.; Liu, X. Biotreatment of the heavy metal pollution in the environment. Chin. J. Vet. Sci. 2009, 29, 1089-1092.

48. Weissmannova, H.D.; Pavlovsky, J. Indices of soil contamination by heavy metals-Methodology of calculation for pollution assessment (minireview). Environ. Monit. Assess. 2017, 189, 616. [CrossRef] [PubMed]

(C) 2018 by the authors. Licensee MDPI, Basel, Switzerland. This article is an open access article distributed under the terms and conditions of the Creative Commons Attribution (CC BY) license (http://creativecommons.org/licenses/by/4.0/). 